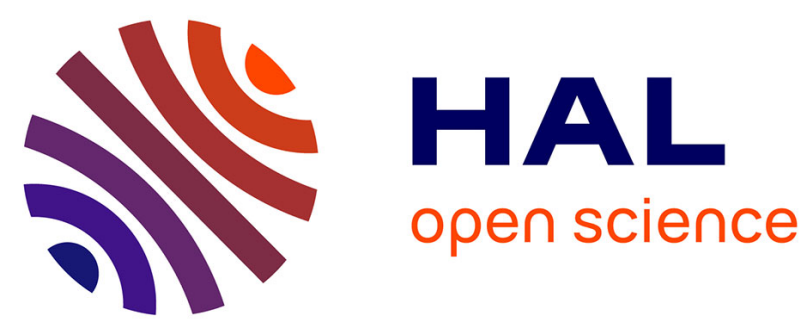

\title{
What Has Popular Music Ever Done for Us? Pleasure, Identity and Role Play in UK Pop Music in the 1970s
}

John Mullen

\section{To cite this version:}

John Mullen. What Has Popular Music Ever Done for Us? Pleasure, Identity and Role Play in UK Pop Music in the 1970s. Etudes Anglaises, 2018, 71, pp.14-28. hal-01966875

\section{HAL Id: hal-01966875 \\ https://hal.science/hal-01966875}

Submitted on 30 Dec 2018

HAL is a multi-disciplinary open access archive for the deposit and dissemination of scientific research documents, whether they are published or not. The documents may come from teaching and research institutions in France or abroad, or from public or private research centers.
L'archive ouverte pluridisciplinaire HAL, est destinée au dépôt et à la diffusion de documents scientifiques de niveau recherche, publiés ou non, émanant des établissements d'enseignement et de recherche français ou étrangers, des laboratoires publics ou privés. 
Mullen, John. « What Has Popular Music Ever Done for Us? Pleasure, Identity and Role Play in UK Pop Music in the 1970s ", Études anglaises, vol. vol. 71, no. 1, 2018, pp. 14-28.

John MULLEN

What Has Popular Music Ever Done for Us? Pleasure, Identity and Role Play in UK Pop Music in the 1970s.

Popular music has been more thoroughly studied from the point of view of the producer (structures, influences, instruments, innovations, etc.) than from that of the "consumer." This contribution looks at 1970s popular music in the UK from the perspective of its use in people's everyday life. Breaking with a tradition of studying niche genres, it concentrates on the number one hits of the time and, looking at "consumers" as active participants in the building of imaginary worlds, it hypothesizes that it is as role play that popular music is best understood. The gendered role plays inherent in new genres such as metal, glam and punk are considered, but also the positionings offered to the "consumer" by pop hits which do not fit into any identifiable genre.

Les études de musique populaire se sont souvent concentrées sur le point de vue des créateurs, étudiant les structures, les influences, les traditions, les instruments ou les techniques. Cet article examine la musique populaire en Grande-Bretagne dans les années 1970 du point de vue du «consommateur » et de l'utilité que peut avoir la chanson dans la vie quotidienne à cette époque. Plutôt que d'analyser les genres musicaux qui ont été pris « au sérieux » par la critique, nous partons des tubes $d u$ «top quarante » de cette époque. Notre approche considère les «consommateurs » comme des participants actifs dans la construction de mondes imaginaires, et soutient que c'est en tant que jeu de rôle qu'on peut le mieux comprendre l'attrait de la musique populaire. Les jeux de rôle genrés inhérents aux genres musicaux comme le métal, le glam ou le punk sont étudiés, ainsi que la place $d u$ « consommateur » de chansons qui ne correspondent à aucun genre musical déterminé.

Popular Music Studies has been an established discipline for several decades. Naturally enough, some aspects and approaches have been prioritised over others. The aim of this article is to give an overview of what 1970s pop music did for British people, while examining some elements I believe have not received the attention they deserve.

Philip Tagg, in his monumental work Music's Meanings, regrets that popular music is almost always studied from the point of view of those who produce it, rather than from the point of view of those who listen to it and engage in other activities connected to its reception (karaoke, singing along, being a fan, dancing, etc.). He insists that we as audiences have developed skills for listening to and interpreting popular music which are worthy of study, in addition to the fact that listeners are far more numerous than producers, and so, from a social science point of view, can reasonably be prioritised (Tagg 195-8).

Christophe Pirenne expresses another regret: that most research concerns a small section of popular music output (Pirenne). Popular music is a huge industry: UK exports alone amounted to 2.5 billion pounds in 2017 (UK Music Report 2017); many thousands of songs are produced every year. This huge corpus leads researchers to choose small segments they 
wish to study, and these segments often correspond to the music the researchers loved when they were teenagers (the present author is no exception: see Mullen 2017). The studies are, in addition, frequently limited to that music which, it is felt, "deserves to be taken seriously." Popular Music Studies still has not gained full legitimacy in academic circles, so a concentration on "serious popular music" may be a defensive tactic from researchers, who will also tend to concentrate on reflective listening by connoisseurs, of the sort also examined in classical music studies.

Finally, those researchers who have worked on the reception of popular music have often chosen to work on "hardcore fans," people who have a very strong social and psychological investment in their favourite music genres (see Mackinnon or Heron, for example). Less has been said about the more everyday mass reception of music which we listen to on the radio, hum in the shower, or hear in the lift (but see Lanza). The present article then, aims at exploring the reception of popular music by non-hardcore UK fans in the 1970s, concentrating on the most "popular" music (that which sold the most). ${ }^{1}$

\section{What Did People Want in the 1970s?}

People like popular music to express desires, fantasies, and worries which are present in their everyday lives: the music helps us to survive. The popular music which gains success often speaks to this need, though its production also depends on the technology and the industry organisation which frame the communication of music. As an example, singalong music hall songs in the early twentieth century had to be consensual, because if only half the theatre sang along, the piece was rated a failure, whereas songs in the vinyl era could be hits even if only five or ten per cent of the general listening population were enthusiastic about them (only nineteen singles among those which entered the UK charts in the 1970s eventually sold a million units).

Let us look at the affective situation of 1970s people in the UK. Describing what "people" wanted differently in the 1970s, compared with other decades, is a topic which is fraught with danger. It can easily lead to "zeitgeist talk" and vast generalisations about the nature of the "baby boomer generation." These simple definitions of generations, generations $\mathrm{X}, \mathrm{Y}$ or Z, are necessary for marketing professionals, who only need to be sufficiently close to the reality to get a little ahead of their competitors, but can be more than shaky for the historian. They depend on an idea of stable society and a homogeneity of social experience, and one can easily forget that diversity and rapid change are the normal stuff of history.

With these provisos, it does seem to me that the 1970s saw the continuing rise of the importance of the individual personality within the conceptions of the mass of the population. The material base for such a development had been established: the post-war boom had brought a sharp fall in absolute poverty (and few things reduce the space for individual personality as quickly as material poverty). Working-class people had felt more secure as mass

\footnotetext{
${ }^{1}$ Given that the artistes and songs mentioned in this article are extremely easy to find on YouTube, I have not given internet links for each reference.
} 
unemployment had become almost a forgotten memory. Although, famously, the economic crisis, welfare cuts and mass unemployment were to come back to the UK in the 1970s, the dynamic of social improvements won in the boom continued to act on people's lives. Infant mortality, a key measure, continued to fall (from 17.7 per thousand live births in 1970 to 11.9 in 1980). In 1970, 50\% of dwellings were owner-occupied; in 1983, $60 \%$ were. In 1970, $65 \%$ of households owned a washing machine. By 1980, 79\% would (Mullen 2016). And even the mass unemployment may not have been as strongly demoralising as in later decades, since it could still be looked at, hopefully, as a temporary glitch.

Families were smaller, lodgings were bigger, ever more teenagers had their own rooms, and were now allowed to individualise them. Life expectancy was rising, and people were getting married later. Fewer young people were following in their parents' footsteps when it came to choosing a job, and geographical mobility, as new industries opened up in different regions of the country, gave people more choice. The advent of supermarkets and the rise of mass fashion, although they gave much space for commercial interests to work on seducing consumers, also represented a rise in choice and individuality compared with previous decades. People had more leisure time, and more choice of radio and television.

A series of legal changes reflected a rise in the idea that lifestyle should involve a considerable amount of personal choice. The decriminalisation of male homosexuality and of abortion in the late $1960 \mathrm{~s}^{2}$ was based on the idea that in the realm of "moral choices," the state should do less to interfere. The changes in divorce laws, ${ }^{3}$ with less emphasis on "fault," went in the same direction. From the abolition of military service and the slow outlawing of physical punishment in schools, to the rise of self-help books (like those of Eric Berne, 1966 and 1975) and the popularity of Paolo Freire and Ivan Illich: signs were everywhere that the further rise of individuality was in the air. This very general picture is confirmed by a number of influential historians (Turner, in particular chapter 14; Ward; Sandbrook 2006; Sandbrook 2013, in particular chapter 17), although it was based, for this article, on the author's personal experience of growing up in Britain in the 1970s.

Many of these processes of social liberalisation had still gone nowhere near as far as they have today: in the 1970s one did not speak of "single-parent families" but of "broken homes" and working mothers might be looked down on as their children were "latchkey kids" supposedly abandoned in the home. Gay people did not often live their sexuality openly: the decriminalisation had not meant welcoming in most circles (Jivani).

\section{What Was 1970s Pop Music?}

Given this rapid sketch of the social psychology of the UK population in the 1970s, what of the popular music? This was a decade in which the UK played a major role, out of all proportion to the weight of the country in international economics and politics. A whole series of genres flourished in Britain, as thousands of musical groups dreamt of popularity or stardom,

\footnotetext{
${ }^{2}$ Sexual Offences Act 1967 (which did not apply in Scotland or in Northern Ireland), Abortion Act 1967 (which did not apply in Northern Ireland, and indeed, still does not).

${ }^{3}$ For example, the Divorce Reform Act of 1969.
} 
and dozens achieved it. An important element of this success was mass activity: there was a time in the late seventies when it seemed a teenage boy needed to have a good reason not to be part of a band. Glam rock hit the headlines in the early seventies, while heavy metal built a healthy minority scene. Reggae groups, previously circulated confidentially in Black communities, broke into the mainstream. Punk, building on roots in New York, became a peculiarly British practice and repertoire for a number of years, while synth pop rounded off the decade with its avant-garde sounds. It does not seem unreasonable to see the 1970s as a Golden Age for British popular music. Although American rock and Motown soul and disco remained tremendously popular, and the biggest seller was the Swedish group ABBA, ${ }^{4}$ British artistes more than held their own: British artistes were at number one in the UK singles charts for 285 weeks out of the 520 weeks in the decade. Of the groups which had multiple number ones, one was Swedish (ABBA), one was from the US (Donny Osmond), and all the others were British (Slade, 10cc, Rod Stewart, T. Rex, Mud, Gary Glitter and The Brotherhood of Man).

The buying of records was at the centre of popular music culture in the 1970s. With the rise of the cassette deck, adults could also, for the first time, listen to music they had chosen in their cars. When not in a car, silence was golden: until 1980 and the marketing of the Sony Walkman in Britain, one could not privately listen to music while walking along the streets, although the marketing of the boombox or "ghetto blaster" in the mid-1970s allowed streetwise youth to listen to and advertise the music they loved.

Radio disc jockeys were becoming more and more influential. BBC Radio, after some decades of considering pop music as an unfortunate phenomenon which should be generally discouraged, had reorganised itself completely in 1967. The new BBC Radio 1 was set up as a direct response to sharp competition from semi-illegal pirate radio stations which had been broadcasting from ships off Britain's coasts (Chapman). The new stations, Radio 1 and Radio 2, were highly successful: in factories, lorry cabs, shops, workshops or sorting offices across the country, the radio was never switched off. On the television, the main event of the week was Top of the Pops when the "Top Twenty" of the week was dramatically counted down, and selected groups mimed to their records in the studio. The week's sales became theatre as masses of teenagers speculated, with media help, on what would be next week's number one, and were appropriately disappointed or ecstatic on hearing the result. Alternatively, the low-budget, late night TV show The Old Grey Whistle Test reflected a tendency to take popular music much more seriously (Mills). It concentrated exclusively on album music, fielding quite lengthy live sets, and presented promising newcomers with a TV platform.

Collective popular music experiences were changing, too. The local dance hall (often in the Conservative Club or the Liberal Club) where young men would ask women to dance, accompanied by a live orchestra, was almost completely replaced by the discotheque (in a club, pub or school hall), where records were played. Dancing in couples became less common, and was often restricted to the last part of an evening. Social mores had changed, single-sex

\footnotetext{
${ }^{4}$ With seven number one singles, staying at the top spot for a total of 26 weeks.
} 
schooling was in sharp decline and opportunities for private contact between men and women were far more common outside dance halls: the need for dance as a courting ritual was less strong.

The 1970s also saw an increase in the number of music festivals. After the legendary Woodstock festival in the USA in 1969, free festivals were organised in Britain, such as the Glastonbury Free Festival in 1971. Their free status corresponded with the ethos of young people at the time, though of course the festivals also helped sell records and popularise artistes. The Isle of Wight festival (in 1968, 1969 and 1970) was no doubt the first one that aimed at being commercially viable. "We were uncool because we weren't free," said one organiser (BBC 2010), but 600000 people came in 1970, to hear US artistes such as Jimi Hendrix and Joan Baez, but also The Who, The Moody Blues and Emerson, Lake and Palmer.

\section{What Identities Did We Enjoy Performing?}

A number of scholars, from Goffman (1956) to Butler (1990), have emphasised the importance of role performance in everyday living, and such conceptions apply easily to popular music, where pretending to be someone else is an important part of the experience, as we shall see. Lawrence Grossberg (1984) speaks of the "empowerment of everyday life" through rock music and posits the idea of "affective alliances" in which large groups of people agree to organise pleasure in particular ways (Grossberg). Rock, he maintains, mostly organised desire around the body and around youth.

In the 1970s, as at other times, leading musical genres allowed multiple phenomena of identification and performance: as well as listening to punk, metal or reggae, one could "be" a punk, a reggae or glam rock fan or a "metal-head," an activity which involved clothing and attitude, and could be pursued on a part-time or full-time basis. Dick Hebdige's classic treatment of youth "subcultures" (Hebdige) saw these performances as forms of cultural resistance. Certainly, the hedonism of glam rock may have been refreshing to explore while Edward Heath was on the TV, calling for a return of the wartime spirit in order to deal with the economic crisis in 1973 or 1974 . During the three-day working week, imposed by Heath as a response to a national miner's strike, Mud's “Tiger Feet" and Suzi Quatro's "Devilgate Drive" were the best-selling singles of the month, both very distant from social comment or political engagement.

In 1977, the Sex Pistols' sarcastic anthem "God save the Queen" got to number two in the official charts as street parties and imperial nostalgia swept the country on the occasion of the silver jubilee of Queen Elizabeth II. Two years later, Ian Dury's post-punk "Hit Me with Your Rhythm Stick" got to number one during the strikes of the "Winter of Discontent," and Blondie's Parallel Lines was at the top of the album charts. It seems fair to say that the performance of an identity as a vocal theatrical punk "loser" was an attractive fantasy to many at this time, and can be seen as social compensation or psychological resistance in the crisis. This despite the fact that the artistes who produced the songs of these new rising genres spoke above all of countering the previous dominant currents of popular music, rather than of reacting to socio-political events. The theatrical partying of Glam contradicted the worship of 
"authenticity" which had characterised progressive rock; the gritty provocations of Punk went against the joyfulness of disco and the positivity of hippy ideology while its approximate guitar playing went against the virtuosity of progressive rock.

The involvement in a subculture could be a life-changing experience. When Heron interviewed some who were punks in the 1970s, one told him: "It was the most enlightening experience I'd ever had." (Heron 574) and another described the punk experience as "a cumulative fuck you to the violence and social conservatism that dominated everything everywhere. Empowerment, escape and energy that the older generations (even those in their 20s) just couldn't understand" (Heron 573). Nevertheless, as I will explain below, the effects and pleasures of identification and performance serve a much wider population than the minority visibly involved in youth subcultures.

\section{Men and Women}

Before studying these more diffuse effects, I would like to look at genres, subcultures and identification in relation to the men and women of the 1970s. The 1970s is the decade of the "second wave" of the British women's liberation movement, bracketed between the first national women's liberation conference in Oxford in February 1970 and the last national women's liberation conference in the UK to date, in Birmingham in April 1978, when differences in political philosophy became so sharp that the national movement collapsed, though it left a good number of local or single-issue campaigns and groupings, and a continuing national magazine, Spare Rib. ${ }^{5}$

The main 1970s music genres seem to have concentrated on new ways of performing masculinity, no doubt because of the male domination of the productions, and the limited public space which was allowed for women's concerns. One of the attractions of glam rock to young working-class men was its vision of an individual, aestheticist manner of being a man, which contrasted strongly with the taciturn, and particularly collective performances of masculinity traditionally available. Such "new masculinity" was particularly tempting to the aspirational section of working class youth (Branch). Playing 6 at being glam was a relief and a release from the rigid rules of being an early 1970s young working-class man. It has even been suggested that glam constituted a reply to misogynous and homophobic rock forms, in that it valorised the feminine side of men, or androgyny (Gregory).

Heavy metal performed an "empowering masculinity" (Weinstein) ${ }^{7}$ progressive rock an entranced poetic one, ${ }^{8}$ and punk the masculinity of a sarcastic loser. Yet genres showing

\footnotetext{
${ }^{5}$ The rich and complex history of the 1970s Women's Liberation Movement in the UK can be followed in considerable detail in archives such as that of Spare Rib, available at https://www.bl.uk/spare-rib and that of Women's Voice, available here https://womensvoicearchive.wordpress.com/ (last accessed 11 May 2018).

${ }^{6}$ I use the word "play" and "games" in a serious sense, to speak of practices which may have felt vital to psychological survival.

${ }^{7}$ Black Sabbath's album Paranoid was number one in the UK album charts in October 1970.

${ }^{8}$ Led Zeppelin 3 was number one in the UK album charts in February 1970; Pink Floyd's Atom Heart Mother in October 1970.
} 
ways of performing femininity were almost totally absent from the popular music scene. Although folk music could allow a performance of wise women with their roots in the mists of time, ${ }^{9}$ and individual artistes could show performances of femininity, entire genres with this as a priority seem to have been absent. Women did of course intervene in all genres as a minority influence, and carved out a space for themselves, as did Suzi Quatro in glam rock (Auslander) or Poly Styrene (Brown) or The Raincoats (O’Meara) in punk. This was possible because the performances being put forward with mostly men in mind were not in any way watertight: an important aspect of popular music is about dreaming of being someone you are not, so just as white listeners could enjoy reggae while imagining themselves as a Rastafarian rebel, so women could imagine themselves as the sarcastic loser embodied by Sid Vicious or the heartbroken crooner played by David Cassidy. Nevertheless, within 1970s genres, female artistes, given the contested space they were allowed in the rock world, (see for example Davies) had to initiate a particular negotiation of styles and meanings which was not necessary for men. Such female-assertive identity performances as Riot grrls were some way off in the future (see Driscoll).

\section{Role Play and Co-Singers in Individual Songs}

If genres and the subcultures which grew up around them could provide an "elsewhere" temporarily to escape from stifling or depressing social norms and class alienation, sometimes involving a comprehensive identification and a life-changing experience, the most common experience of popular music was much lighter and more everyday. One of the key pleasures in popular music, I am claiming, is the appropriation involved for an average listener in playing the role of star, singer or narrator.

What happens when we listen to a popular song? It seems clear that the transfer of information is not at the centre of the experience. When Slade sang in 1972 "Mama, we're all crazy now!"10 they were not intending to inform anyone about the state of their mental health. When Paper Lace sang "Billy, Don't Be a Hero,"11 they were not addressing their instructions to soldiers or anyone else. Since a popular song is listened to dozens of times, often over a very short period, information cannot be at the centre of its role (and this highly repetitive consumption marks popular songs out from other text-based cultural consumptions, such as novels, or even poems).

A good part of the reason for their success, I suggest, is the positioning proposed to the listener. An important part of the experience of popular music, I hypothesise, is singing along, or imagining oneself singing along, with the artiste, with the listener becoming what I term a "co-singer." The audience sing along at a concert; we sing in the shower or in the street, or while doing the housework and listening to the radio. We sing snatches of a song when there

\footnotetext{
${ }^{9}$ Fairport Convention's Liege and Lief, with Sandy Denny as lead singer, stayed in the top twenty of the UK album charts for fifteen weeks in early 1970. Steeleye Span's All Around My Hat remained in the top twenty albums for 20 weeks in 1975.

${ }^{10}$ Number one single in September 1972.

${ }^{11}$ Number one single in March 1974.
} 
is no radio on. Even when we do not utter a sound, if we know a song by heart, we may be "singing along" in silence with the artiste.

From this point of view, popular song is experienced as participative theatre, or role play. The songwriter's job is to propose a role which they think the audience would like to embody for a moment. The Police's single "Message in a Bottle" allows each of us to be the narrator who expresses his loneliness and then discovers his experience is widely shared:

\author{
Walked out this morning \\ Don't believe what I saw \\ A hundred million bottles \\ Washed up on the shore \\ Seems I'm not alone at being alone \\ A hundred million castaways \\ Looking for a home.
}

I sing along with the singer: at a minimum, he is singing for me. This text and this voice may be expressing a part of the personal experience of the artiste, but it is also anchored in an intuitive understanding of what roles the listening public would like to share, what roles this audience needs to play at embodying. And these roles depend in part on the social reality of the time. In the 1910s, music hall audiences, of whom most knew what poverty and hunger felt like, liked to sing along with hymns to good food ("Boiled Beef and Carrots," "Hot Meat Pies, Saveloys and Trotters"). ${ }^{12}$ 1970s role plays were different, expressing other desires.

What are the roles which attract us most? Most often, we would like to play someone more interesting, more daring, less timid and more remarkable, or perhaps more expressive, romantic and poetic than we generally manage to be in our everyday life. Singing snatches of "I'm the Leader of the Gang," 13 I am momentarily a powerful and flamboyant gang leader:

I'm the leader, I'm the leader, I' $m$ the leader of the gang, I am

I'm the leader, I'm the leader, well, there's no one like the man I am

I can take you high as a kite every single night

I can make you jump out of bed standing on my head.

The echoing of the voice and the haunting drumbeat assist in the considerable suspension of disbelief required.

For any given song, the listener has several options of appropriation (which may be activated in parallel). They may appropriate, wholly or partially, the identity of the star, of the singer, or of the narrator. ${ }^{14}$ When we imagine ourselves in the role of the star (listening, say to

\footnotetext{
${ }^{12}$ A recording from the time of Harry Champion singing "Boiled Beef and Carrots" can be found at https://www.youtube.com/watch?v=7mIMIUqAa3w (last accessed 11 May 2018).

${ }^{13}$ Number one in 1973, sung by Gary Glitter.

${ }^{14}$ These distinctions are based on those established by popular music scholar Stéphane Hirschi. See Hirschi.
} 
Led Zeppelin's live album The Song Remains the Same $),{ }^{15}$ in our game the applause before and after the song is for us. The fine musicians are there to accompany me, and no one else; my air guitar playing is entrancing the crowd; my bright clothes and wavy locks of hair look, I must admit, rather good. As co-star, I enjoy inviting the crowd to join in the magic of rock.

Or we may take on some characteristics of the singer: of the physical singing body involved in the production of the song. In this case, as co-singer, we borrow not only the prestige and aura of the star, and not just the texts of the lyrics, but also the diction, the volume, the intonation, the voice. We have our excuse to be louder, more tender or raucous than our everyday communication with people allows us to be. We can let out emotions which are hard to define but easy to sing. We can choose a song which allows us to scream, whisper or whine. Singing along with Kate Bush ${ }^{16}$ in a very high-pitched voice or with Lee Marvin ${ }^{17}$ in a very low-pitched voice allows us an expressivity rare elsewhere in our lives. The stuttering voice of the lead singer from The Who in "My Generation" (released in 1965 but the most popular of their songs throughout the 1970s) allows the expression of fragility at the same time as anger and rebellion:

People try to put us d-down (Talkin' 'bout my generation)

Just because we g-g-get around (Talkin' 'bout my generation)

Things they do look awful c-c-cold (Talkin' 'bout my generation)

I hope I die before I get old (Talkin' 'bout my generation)

This is my generation

This is my generation, baby

Why don't you all f-fade away (Talkin' 'bout my generation)

And don't try to dig what we all s-s-say (Talkin' 'bout my generation)

I'm not trying to cause a big s-s-sensation (Talkin' 'bout my generation)

I'm just talkin' 'bout my g-g-g-generation! ${ }^{18}$

On the other hand, when, as co-singer, we take on the voice of Sid Vicious in the Sex Pistols version of My Way ${ }^{19}$ we can use a loudly sarcastic expressivity from the first note to the last.

Regrets, I've had a few

But then again, too few to mention

But dig what I had to do

I'll see it through without devotion

I planned, each chartered course

Each careful thought along the highway

\footnotetext{
${ }^{15}$ Number one in the UK album charts in November 1976.

${ }^{16}$ Her single "Wuthering Heights" was number one in March 1978.

${ }^{17}$ The US star Lee Marvin was number one in the UK singles chart in March 1970 with "Wandering Star."

${ }^{18}$ The Who, “My Generation” 1965.

${ }^{19}$ The album containing this track, The Great Rock'n Roll Swindle, reached number seven in the UK album charts in 1979.
} 
And more, much more than this

I did it my way

There were times, I'm sure you knew

When there was fuck, fuck all else to do

But through it all, when there was doubt

I shot it up, or kicked it out

I faced the wall ... and ... the wall

And did it my way. ${ }^{20}$

\section{Narrator}

The third and final role we can take on as co-singer is that of co-narrator, and this is no doubt the richest and most varied. Remembering that the song will be sung, in full or in snatches, many, many times, the psychological effect of our taking on the role proposed to us is not to be underestimated. Most narrator roles proposed to us are personal in nature -we can be the lovesick youngster singing "Daydreamer" with David Cassidy, ${ }^{21}$ or "All Kinds of Everything" with Dana, ${ }^{22}$ or, in a somewhat racier style, singing "Hanging on the Telephone" with Blondie. ${ }^{23}$ We can be the world class footballer singing confidently about the fans "Back Home." ${ }^{24}$ We can be the hippies who went to Woodstock, ${ }^{25}$ or the poet paying tribute to a great painter. ${ }^{26}$ We can be a sentimental, doting uncle ${ }^{27}$ or a confident young man showing off his girlfriend. ${ }^{28}$ We can play the dying man philosophising with Terry Jacks's "Seasons in the Sun" ${ }^{29}$ or speak up for morale at the beginning of the New Year. ${ }^{30}$

Some roles are more political. Pink Floyd's Number one hit "Another Brick in the Wall" is a hyperbolic denunciation of traditional education. ${ }^{31}$

We don't need no education

We don't need no thought control

No dark sarcasm in the classroom,

Teacher, leave those kids alone!

All in all, you're just another brick in the wall.

\footnotetext{
20 "My Way" by the Sex Pistols, 1979.

${ }^{21}$ Number one in October 1973.

${ }^{22}$ Number one in April 1970.

${ }^{23}$ A song which reached number five in the UK singles chart in 1978.

${ }^{24}$ In May 1970, the England football squad reached number one in the singles charts with their song "Back Home."

${ }^{25}$ The British band Matthew's Southern Comfort, reached number one in the UK singles chart in October 1970 with a cover version of Joni Mitchell's song "Woodstock."

${ }^{26}$ US singer Don McLean reached number one in June 1972 with his tribute to Van Gogh.

${ }^{27}$ The Irish singer, Gilbert O'Sullivan, reached number one with a love song which featured an uncle's feelings for his niece, Claire, in November 1972.

${ }^{28}$ Wizzard reached the number one spot with "See My Baby Jive" in May 1973.

${ }^{29}$ Terry Jacks reached number one with "Seasons in the Sun" in April 1974. The song is a very much simplified and polite, translated version of Jacques Brel's "Le Moribond," "The Dying Man."

${ }^{30}$ The group Pilot reached number one with their song "January" in February 1975.

${ }^{31}$ The song stayed at number one for several weeks from November 1979.
} 
This chorus allowed the co-singer (who would often still be at school themselves) to denounce the feeling of being restricted in the school context, and its success was no doubt also linked to the fact that "dark sarcasm" and bullying by teachers were considerably more common at the time than they are today: the slow disappearance of physical punishment in British schools was just one aspect of a rise in the level of respect for young people in schools and elsewhere.

Another notable example of a hit song with political implications was "The Killing of Georgie," released by Rod Stewart in 1976, a tragic tale of a gay man murdered by a homophobic street gang. The song reached number two in the singles charts at a time when homophobia was more likely to be taken for granted than was defence of diversity. The lyrics begin by telling the story of Georgie:
Georgie boy was gay I guess
Nothin' more or nothin' less
The kindest guy I ever knew
His mother's tears fell in vain
The afternoon George tried to explain
That he needed love like all the rest
Pa said there must be a mistake
How can my son not be straight
After all I've said and done for him?

Whereas the last line of the song - "Georgie was a friend of mine" - represented at the time something quite new, and the fact that it was sung by a well-established star is striking. The decriminalisation of male homosexuality for over $21 \mathrm{~s}$ had by no means ended homophobia, as is shown by the fact that the very first Member of Parliament to dare to openly declare their own homosexuality was only in 1984.

The role-play proposed by individual songs is, just as is that proposed by genres, affected by gender. Despite the fact that pop music is about pretending we are somebody else, some narrators are clearly marked as masculine, and might not be easy for women to identify with (take for example "See My Baby Jive" by Wizzard). Other narrators (take the example of the song "I will Survive" by Gloria Gaynor, ${ }^{32}$ or "Space Oddity" by David Bowie ${ }^{33}$ ) would seem to be fairly easy to appropriate by listeners of either gender. Detailed analysis of the gendering of narration and appropriation in the 1970s pop song is beyond the scope of this article, though I feel it would be a fruitful endeavour.

Apart from the question of gender, there are a number of other considerations to be taken into account. I will mention only one here: identification with a type of narrator can very much influence the general structure of our musical taste. Those people who, in the 1970s, did

\footnotetext{
${ }^{32}$ Number one in March 1979.

${ }^{33}$ Number one in November 1975.
} 
not enjoy identifying with laid-back spiritual Black Jamaicans were unlikely to be fans of reggae; those who did not want to identify, even for three minutes, as sarcastic losers were unlikely to like punk; those who did not wish to play at loud explorations of satanic ritual were not made to be heavy metal fans; those who did not imagine themselves as village minstrels singing the harvest in did not choose folk music. The games we wished to play fit the genres of music we bought.

This contribution is for a volume concerned with a particular historical period, the $1970 \mathrm{~s}$, but 1970s music is still listened to today, and the modalities of identification/participation I have posited might apply at least in part to more recent, and to previous musics. These modalities have been explained here from a somewhat intuitive or even perhaps speculative base: surveys or tests of people's specific experiences of reception of particular songs would help take these hypotheses further. In particular it would be fruitful to find ways of testing whether men and women receive differently male and female narrators, and whether White people receive Black narrators in specific ways and vice versa.

This article has aimed at exploring 1970s popular music in a slightly new way, looking at how listeners appropriated the music on an individual level, in the context of what were becoming established as appropriate desires and fantasies for the end of the post-war boom. It has concentrated on the least spectacular, most "banal" ways of consuming and appropriating music, and on the best-selling music of the times. It has been an initial exploration, and far from exhaustive, but it has seemed to us that this point of view is necessary, as part of a vision of "history from below" and as concomitant with the intention of bringing ever closer the history of popular music and the history of society.

John MULLEN

Université de Rouen-Normandie

ERIAC EA4705

\section{Bibliography}

Auslander, Philip. “I Wanna Be Your Man: Suzi Quatro's Musical Androgyny.” Popular Music, 23:1, 2004. 1-16.

Berne, Eric. Games People Play: The Psychology of Human Relationships. London: André Deutsch, 1966.

---. What Do You Say after You Say Hello? The Psychology of Human Destiny. London: Corgi books, 1975.

Branch, Andrew. "All the Young Dudes: Educational Capital, Masculinity and the Uses of Popular Music.” Popular Music, 31:1, 2012. 25-44.

British Broadcasting Corporation. Festivals Britannia, TV documentary, 2010. 
Brown, Jayna. "Brown Girl in the Ring": Poly Styrene, Annabella Lwin, and the Politics of Anger. Journal of Popular Music Studies, 23, 2011. 455-478.

Butler, Judith. Gender Trouble: Feminism and the Subversion of Identity. London: Routledge, 1990.

Chapman, Robert. Selling the Sixties: The Pirates and Pop Music Radio. London: Routledge, 1992.

Davies, Helen. "All Rock and Roll Is Homosocial: the Representation of Women in the British Rock Music Press.” Popular Music, 20:3, 2001. 301-319.

Driscoll, Catherine. "Girl Culture, Revenge and Global Capitalism: Cybergirls, Riot Grrls, Spice Girls.” Australian Feminist Studies 14:29, 1999. 173-193.

Freire, Paolo. Pedagogy of the Oppressed. Harmondsworth: Penguin, 1972.

Goffman, Erving. The Presentation of Self in Everyday Life. Edinburgh: Edinburgh University Press, 1956.

Gregory, Georgina. "Masculinity, Sexuality and the Visual Culture of Glam Rock." Culture and Communication, 5:2, 2002. 35-60.

Grossberg, Lawrence. "Another Boring Day in Paradise: Rock and Roll and the Empowerment of Everyday Life.” Popular Music, vol. 4, 1984. 225-258.

Hebdige, Dick. Subculture: the Meaning of Style. London: Routledge, 1979.

Heron,Timothy. Alternative Ulster : Le punk en Irlande du Nord (1976-1983), unpublished Ph D thesis, defended at the University of Reims, 17 November 2017.

Hirschi, Stéphane. Chanson. L'art de fixer l'air du temps : de Béranger à Mano Solo. Paris : Les Belles Lettres, 2008.

Illich, Ivan. Deschooling Society. Harmondsworth: Penguin, 1973.

Jivani, Alkarim, It's Not Unusual, A History of Lesbian and Gay Britain in the Twentieth Century, London: Michael O’Mara books, 1997.

Lanza, Joseph. Elevator Music: A Surreal History of Muzak, Easy-Listening, and Other Moodsong. Ann Arbor: University of Michigan Press, 2004.

MacKinnon, Niall. The British Folk Scene: Musical Performance and Social Identity. London: Open University Press, 1993.

Mills, Peter. "Stone Fox Chase: The Old Grey Whistle Test and the Rise of High Pop Television" in Ian Inglis (ed.), Popular Music and Television in Britain, Aldershot: Ashgate, 2010.

Mullen, John. Britain in the 1970s- an Annotated Timeline. Saint-Gratien: STAReBOOKS, 2016. 
Mullen, John. "What Can Political Music Do? An Exploration Based on the Example of the Tom Robinson Band 1976-1979.” Revue française de civilisation britannique, 22 :3 , 2017.

O'Meara, Caroline. “The Raincoats: Breaking down Punk Rock's Masculinities.” Popular Music, 22 :3, 2003. 299-313.

Pirenne, Christophe. "Les musiques populaires dans l'enseignement et la recherche universitaire musicologique en France". Intervention lors de la journée d'études IASPM branche francophone d'Europe, Du manque de discipline des musiques populaires. Strasbourg, 15 octobre 2016.

Sandbrook, Dominic, Never Had It So Good, A History of Britain from Suez to the Beatles, London: Abacus, 2006.

Sandbrook, Dominic, Seasons in the Sun-The Battle for Britain 1974-1979, Harmondsworth: Penguin, 2013.

Tagg, Philip. Music's Meanings. New York: Mass Media Music Scholars' Press, 2012.

UK Music Report: Measuring Music 2017.

https://www.ukmusic.org/assets/general/Measuring_Music_2017_Final.pdf

Turner, Alwyn W. Crisis, What Crisis? Britain in the 1970s (2008). London: Aurum, 2009.

Ward, C. The Child in the City. London: The Architectural Press, 1977.

Weinstein, Deena. “The Empowering Masculinity of British Heavy Metal.” Ed. Gerd Bayer, Heavy Metal Music in Britain, London: Routledge, 2016. 